\title{
THE PROJECT-BASED ASSESSMENT LEARNING MODEL THAT IMPACTS LEARNING ACHIEVEMENT AND NATIONALISM ATTITUDES
}

\author{
I Wayan Widiana*, I Made Tegeh, I Wayan Artanayasa \\ Universitas Pendidikan Ganesha, Indonesia \\ *e-mail: wayanwidiana85@undiksha.ac.id
}

\begin{abstract}
Globalization gives a negative influence on children's nationalism. This is exacerbated by the low students' learning achievement in the social studies education (SSE), despite the fact that one of the objectives of the SSE learning is to develop students' potentials to be sensitive to social problems in the person, the society, the nation, and the state. This study is aimed at describing the effectiveness of the project-based assessment learning model with national insight- oriented activities on the SSE learning achievement and nationalism attitudes of primary school students. The study is quasi-experimental research with a non-equivalent pre-test post test control group design. The research population consisted of all fourth-grade students totaling to 231 in number. Sampling was done by the random sampling technique, resulting in 46 students. Data were collected using test and non-test techniques. The test instrument was a multiple-choice test and the non-test instrument was a five-scale questionnaire. Both instruments were subjected to validity and reliability testing. The data analysis technique used the MANOVA statistic with the help of the SPSS computer software. The results showed that the significance level of the MANOVA test was $.000(<.0)$. This means that there are significant differences both partially and simultaneously in the SSE learning achievement and nationalism attitudes between students who learn by applying the project assessment learning model and students who learn ny applying the conventional learning model. In other words, there is a positive significant effect of learning using the project-based assessment learning model oriented on nationalism-insight activities towards the students' SSE learning achievement and nationalism attitudes.
\end{abstract}

\section{Keywords: nationalism attitude, nationalism insight, project-based assessment.}

\section{MODEL PEMBELAJARAN DENGAN PENILAIAN PROYEK YANG BERDAMPAK PADA HASIL BELAJAR IPS DAN SIKAP NASIONALISME}

\begin{abstract}
Abstrak: Globalisasi memberikan pengaruh negatif terhadap sikap nasionalisme anak. Hal ini diperparah dengan rendahnya hasil belajar IPS siswa, padahal salah satu tujuan pembelajaran IPS adalah mengembangkan potensi siswa agar peka terhadap masalah sosial secara pribadi, masyarakat, bangsa, dan negara. Penelitian ini bertujuan untuk mendeskripsikan efektivitas pembelajaran dengan penilaian proyek berbasis aktivitas wawasan kebangsaan terhadap hasil belajar IPS dan sikap nasionalisme siswa Sekolah Dasar. Jenis penelitian ini adalah penelitian kuasi-eksperimental dengan non-equivalent pre-test post-test control group design. Populasi penelitian adalah seluruh siswa kelas IV yang berjumlah 231 siswa. Sampel diambil dengan teknik random sampling yang berjumlah 46 siswa. Data dikumpulkan dengan menggunakan teknik tes dan nontes. Instrumen tes berupa tes pilihan ganda dan instrumen nontes angket skala lima. Kedua instrumen sudah dilakukan analisis kualitas kelayakannya dengan pengujian validitas dan reliabilitas. Teknik analisis data menggunakan manova dengan bantuan SPSS. Hasil penelitian menunjukkan bahwa angka signifikansi hasil uji manova $0,000(<0,0)$. Ini berarti bahwa ada perbedaan baik secara parsial dan studi secara simultan hasil belajar IPS dan sikap nasionalisme siswa yang belajar dengan menerapkan penilaian proyek berbasis wawasan kebangsaan. Jadi, terdapat efek positif dari pembelajaran dengan penilaian proyek berbasis aktivitas berwawasan kebangsaan terhadap hasil belajar IPS dan sikap nasionalisme.
\end{abstract}

Kata Kunci: sikap nasionalisme, wawasan kebangsaan, penilaian proyek. 


\section{INTRODUCTION}

The era of globalization and industrial revolution 4.0 has brought about some negative impacts on the cultural realities of the Indonesian people. Norms that are contained in the cultures of the Indonesian people have gradually begun to fade. One of the negative impacts of globalization is the declining of the students' nasionalism values at school (Budiarto, 2020; Furqan, Yanti, Azis, Kamza, \& Ruslan, 2020; Setiawan, 2017). This can be seen from students' attitudes in doing the school flag-raising ceremony: they do not show serious postures, play with their friends, and do not respect the proceding of the ceremony; preferring foreign products to dometic products; having a low level of interest in preserving Indonesian cultures as national idetities; and exhibitting an inclination of breaking the rules. Certainly, this condition is not one that is in line with what is espected, whereby primary-school students are in their golden ages, in which they must be taught social norms and values such as nasionalism (Huda \& Nurwardani, 2013). One of the ways to implant nationalism into children is through social science education (SSE).

SSE learning is very much related to the aspects of knowledge, skills, attitudes, and values that enable the learners to participate in the community where the learners live. SSE is learning that gives the oppotunity for the learners to exercise their comprehensive perspectives concerning social and humanistic sciences as their capital to become good state citizens (Widnyani, Suara, \& Wiyasa, 2015). The importance of SSE learning demands the teachers to be able to develop the teachinglearning design well in order that the instructional objectives of the SSE learning are achieved and produce community members who have nationalism values and attitudes. Good learning is one that can improve students' higher-order thinking skills (HOTS) and creativities (Gurung, 2020; Henriksen, Richardson, \& Shack, 2020; Idris, Sida, \& Idawati, 2019).

A documentary study conducted in a number of primary schools in Bali Province shows that students' achievement in SSE classes is still low. Many students are not highly motivated and and involved in the SSE learning processes and there are those who have not completed the outcome requirements (Sulfemi, 2019;
Suryani \& Aman, 2019; Wahyuni, Slameto, \& Setyaningtyas, 2018; Nurdin, 2016; Rusmawan, 2013). Qualitatively, it is found that students' experience difficulties in finishing task items that are based on problem solving. In addition, the results of an observation also find that students' motivation in SSE classes is very low and that students do not look anthusiastic in joining the instructional activities in the SSE classes; many even often daydream during classes. It is gathered that the low level of students' learning motivation is due to the learning processes that are not interesting. The learning processes still tend to be passive; in running the class, the teacher seldom uses instructional media despite the fact that there are a lot of them available at school; the teacher has not related the learning processes to the problems around the school; the teacher does not train students in using higherorder thinking skills (HOTS); and the teacher even does not use social problems as learning materials and activities. It is why the students find it difficult to understand the lesson but merely memorize the class materials. This situation also has an impact in the low level of students' learning achievements (Setyasto \& Wijayama, 2017). Besides, the use of monotonous teaching method makes the students feel bored and tired in attending the class and the teacher does not teach in line with the standard which makes the class activities sidetracted and focused merely on the textbook contents (Heafner \& Fitchett, 2012; Ollila \& Macy, 2018). In order to prevent this condition to become worse, teachers must continue making innovations in their teaching classes in line with on-going technological development. Teachers must be able to develop teaching and learning proccesses and activities that are in line with the learners' characteristics.

At present, many have been innovated in the SSE learning processes in order to elevate students' learning achievement. One of these these has been the implementation of instructional models that are innovative. Some of these models that have been implemented in SSE classes are cooperative learning, problembased learning, inquiry learning, and some other innovative methods. A number of studies have been conducted to improve SSE learning. Rosidah (2017), one of these, shows that a learning model of the Snowball-Throwing type is able to improve students' learning 
achievement. In her study, Sari (2014) states that the use of the cooperative learning model of the jigsaw type in an SSE class has an impact on the improvement of the students' learning achievement. Meanwhile, Matondang (2017) reports that the learning model Listening Teams is able to increase the instructional activities and improve the students' learning outcome in term of the classical thorough learning in the subject matter of History in SSE. It must be noted that these learning models have emphasized on how the learners work in their groups that develops their social competences rather than their abilities to think critically and creatively. Also, learning tasks that give problems too difficult for students may tend to reduce students' enthusiasm to learn and may even make them feel frustrated (Nagge, Killeen, \& Jennings, 2018; Şendağ \& Odabaşi, 2009). Besides, the evaluation process that is carried out at present tends to measure knowledge as compared to students' skills and attitudes.

In order to help overcome these problems, a learning innovation is needed that makes a combination between project assessment and national frame of reference. Assessment in an instructional process is not a tool for increasing lesrners' grades; but it is more for providing learners with the knowledge that can be used actively to solve a problem or do an instructio nal task (Black \& Wiliam, 2018; Leong, Ismail, Costa, \& Tan, 2018). This learning innovation is intended to develop learning processes that emphasize on activating students (McCulley \& Osman, 2015). Learning models using assessment are very seldom implemented; however, a number of studies have shown that this assessment model is effectyive to be used in instruction. Studies by Mak \& Lee (2014) and Ranalli, Feng, \& Chukharev-Hudilainen (2018) show that assessment in learning can improve students' writing competences. DeLuca, Luu, Sun, \& Klinger (2012) show that assessment for learning (AfL) is one of the pedagogical approaches that can improve learners' learning processes. Meanwhile, the study by Lee \& Coniam, (2013) shows that, involving the learners in the evaluation processes gives a positive impact on the improvement of their learning processes.

One of the evaluation processes that can be done by the techer is one that is project-based.
The project-based assessment is categorizable into authentic evaluation. Authentic evaluation is focused on students' higher-order thinking and problem solving (Farrell, 2020; Tungkasamit \& Junpeng, 2012). Project-based evaluation can improve learners' skills in leadership, communication, collaboration, and problem solving and it can involve the cognitive, affective, and psychomotor domains (Shariff, Johan, \& Jamil, 2013). Project-based authentic evaluation is used to make sure that learners have understood basic concepts being taught (Keinänen, Ursin, \& Nissinen, 2018; Lefebvre \& Luo, 2020).

Project-based evaluation can also motivate learners in the instructional process so that they can learn substantially more about the instructional contents (Sari, Mauliza, Nazar, \& Nahadi, 2020). A study by Fazriah, Suara, \& Wiyasa (2015) shows that project assessment can improve students' learning achievement in SSE learning and their reasoning abilities for the reason that it helps them in being more creative in producing a result by relating the instructional material they receive to their daily life. Meanwhile, a study by Andewi, Suara, \& Wiyasa (2015) shows that the implementation of the scientific approach coupled with project assessment is effective in improving learning achievement in SSE skills and in understanding the concepts of future ambition in the fourth graders. The students' characters and learning achievement indicate a thorough grade shown by their good behaviours and attitudes.

By looking at all the studies described above, it can be said, in general, that the use of project-based evaluation has positive impacts on learning processes. It is this advantage that has become a trigger for the implementation of instruction with project-based evaluation which is oriented on nationalism-insight activities. This learning model gives students the opportunity to make a project in solving a problem. The projects are, among others, staging a play, producing a comic, a role-play project, producing a historical calendar, producing a daily newspaper, and building a wall magazine. These projects are developed on the basis of nationalism-insight activities both in the project theme and cooperative work, group discussion which take into consideration the opinions of all the group members, and tolerence among the 
school members.

The objective of the present study is then to describe the effectiveness of the project-based evaluation learning model using nationalisminsight activities over the SSE learning outcome and nationalism attitudes of the primary school students. All the activities in the learning process are assessed by project-based evaluation in a structured and systematic way. Project evaluation becomes the dominant aspect of this learning model since all the assessment phases are developed and implemented thoroughly in the instructional process from the designing phase to the implementation and learning evaluation. It is expected that the instructional process has a positive impact on the students' development both in term of their learning achievement and nationalism attitudes. This is because students are more active in constructing and developing their own knowledge through the process of producing a project in a group. With the implementation of project-based evaluation, students are more motivated in their learning processes since they know right away, without delay, the results of their work. In addition, the combined activities of the nastionalism insights help in developing their attitudes of cooperative working, hard-working, appreciating others' opinions, responsibility, and tolerance.

\section{METHOD}

The study was quasi-experimental research with a non-equivalent pre-test post-test control group design. In the research treatment, the experiment group was taught by using project-based evaluation with nationalisminsight activities while the control group was taught by using the conventional evaluation process. The two research groups received a pretest and post test to find differences in scores at the end of the treatment.

The research population was designated as all grade-4 students in nine schools in Sukasada District, Bali, Indonesia. Sampling was done by the random sampling technique after population equalization was conducted. An ANOVA test of equaivalence found that the population was equal. The experiment group consisted of 22 students of Primary School 5, and the control group consisted of 24 students of Primary School 4. The experiment group received the experimental treatment of project-assessment based learning with nationalism contents and the control group received the conventionalassessment treatment.

Data collection was conducted by two techniques, namely an SSE test battery and an attitude questionnaire for nationalism. The SSE test instrument consisted of 30 multiple-choice test items measuring nationalism attitudes in the theme of various occupations divided into four sub-themes. The level of difficulty for the test items was aligned to the cognitive measure of grade four of the primary school. These consisted of 5 items of $\mathrm{C}_{2}, 7$ items of $\mathrm{C}_{3}, 12$ items of $\mathrm{C}_{4}$, and 6 items of $\mathrm{C}_{5}$. The test was subjected to a validity and reliability measurement. For validity, the CVR test showed that all the 30 items were valid with scores ranging from .71 to 1.00. For reliability, a Cronbach Alpha reliability coefficient of .801 was obtained. The nationalism questionnare consisted of 25 items constructed from the dimensions of patriotism, willingness to sacrifice for the sake of the common interests, preservation of national cultures, and care for others. Specification of the indicators for the questionnaire items is presented in Table 1. The questionnaire was subjected to a validity and reliability test. The CVR results showed that all the 25 items were valid and reliable.

\section{Table 1. Specification of Items of the Nationalism Questionnaire}

\begin{tabular}{llc}
\hline No Dimension & Indicator & $\begin{array}{c}\text { Number of } \\
\text { Items }\end{array}$ \\
\hline 1 Patriotism & a. Love the motherland and be proud of being an Indonesian & 2 \\
& citizen & 2 \\
& b. Appreciate the virtue of the heroes & 2 \\
2 Willingness to sacrifice & a. Prsevere, not surrender & 2 \\
for the sake of the & b. Avoid egoistic attitudes & 2 \\
common interests & & 5 \\
3 Preservation of national & a. Participate in preservation of national cultures & 4 \\
cultures & b. Take care of public facilities & 3 \\
4 Care for others & a. Be willing to help others in needs & 3 \\
\hline
\end{tabular}


The pre-test data were analyzed using the descriptive statistics and inferential $t$ test. The post test data were analyzed using the descriptive statistics and inferential Manova. The inferential statistics testing was preceded by the prerequisite tests for normality, homogeneity, and multicorrelation. All statistical calculation was done by the help of the SPSS 25.0 for Windows computer sofware.

\section{FINDINGS AND DISCUSSION Findings}

The study has been aimed at finding out the impacts of project-based evaluation learning oriented on nationalism insight activities over students' learning achievement and nationalism attitudes. Findings of the study give the expected results whereby there is a positive influence of the project-based evaluation treatment over learning achievement and nationalism attitudes. In details, the results of the data descriptive analyses of the data are presented in Table 2.
The first prerequisite test for the pre-test data is the normality test using the KolmogorovSmirnov statistic. Results of the normality test show that the pre-test data are in a normal distribution (Sig. $>.05$ ) with the scores of .149 for learning achievement and .186 for nationalism attitudes. The second prerequisite test is that for data homogeneity and the results show that data for both learning achievement and nationalism attitudes are homogeneous at the significance of .963 (learning achievement) and .753 (nationalism attitudes), which are higher than .05. Based on the prerequite test results that the pre-test data have a normal distribution and homogeneity, the meandifference $t$ test can be conducted. Results of the $t$ test show a significance score of .955 for learning achievement and .600 for nationalism attitudes. This shows that the experiment group and control group are not significantly different since the two significance scores are higher than .05 .

Table 2. Results of Descriptive Analyses of the Pre-test and Post Test

\begin{tabular}{|c|c|c|c|c|c|c|c|c|}
\hline \multirow{3}{*}{ Statistics } & \multicolumn{4}{|c|}{ Achievement } & \multicolumn{4}{|c|}{ Nationalism Attitude } \\
\hline & \multicolumn{2}{|c|}{ Pre-test } & \multicolumn{2}{|c|}{ Post test } & \multicolumn{2}{|c|}{ Pre-test } & \multicolumn{2}{|c|}{ Post Test } \\
\hline & $\mathrm{X1}$ & $\mathrm{X} 2$ & $\mathrm{X} 1$ & X2 & $\mathrm{X} 1$ & $\mathrm{X} 2$ & $\mathrm{X1}$ & $\mathrm{X} 2$ \\
\hline$N$ & 22 & 22 & 22 & 22 & 24 & 24 & 24 & 24 \\
\hline Mean & 66.73 & 67.95 & 86.59 & 84.68 & 66.38 & 67.00 & 76.87 & 78.54 \\
\hline Maximum & 80 & 80 & 100 & 95 & 80 & 80 & 56 & 90 \\
\hline Minimum & 50 & 50 & 75 & 75 & 50 & 50 & 90 & 70 \\
\hline Standard deviation & 1.08 & 10.67 & 8.49 & 7.20 & 1.02 & 10.21 & 1.01 & 6.80 \\
\hline
\end{tabular}

Note: $\mathrm{X} 1=$ Experiment class; $\mathrm{X} 2=$ Control Class

Results of the Kolmogorov-Smirnov normality tests show that all sets of data come from groups that have a normal distribution, i.e. Sig. > .05. The complete results of the normality tests are shown in Table 3. For the homogeneity tests, two statistics are used: Levene's Test of Equality and Box's Test of Equality of Covariance Matrices. The two statistic tests of homogeneity give the same results that the research data are homogeneous seeing that the significance scores are higher than .05. The Levene's test shows a score of .264 for learning achievement and .565 for nationalism attitudes. Meanwhile, the Box's test shows an $F$ score of .271 at Sig. $=.846$. The next prerequisite test is that for multi-corelation to find out the nature of the relationship among the research variables. Using the Tolerance and VIP scores, the multi-corelation test results show a Tolerance score of .759 and VIP score of 1.317 , indicating that there is no multi-corelation between learning achievement and nationalism attitudes.

Table 3. Results of Normality Tests

\begin{tabular}{|c|c|c|c|c|}
\hline & \multirow{2}{*}{ Model_learning } & \multicolumn{3}{|c|}{ Kolmogorov-Smirnova } \\
\hline & & Statistic & $d f$ & Sig. \\
\hline \multirow[t]{2}{*}{ Achiev_learning } & Project-based evaluation & .154 & 22 & 190 \\
\hline & Conventional evaluation & .134 & 24 & .200 \\
\hline \multirow[t]{2}{*}{ Atti_nationalism } & Project-based evaluation & .182 & 22 & .156 \\
\hline & Conventional evaluation & .131 & 24 & .200 \\
\hline
\end{tabular}


The statistical prerequisites for the MANOVA having been fullfilled, whereby showing that the research data have a normal distribution, are homogeneous, and do not indicate multi-correlation, the hypothesis testing procedure can be conducted. The results of the MANOVA test are presented in Tables 4 and 5.

The results of the data analyses produce a number of findings. First, the MANOVA analysis results show the Pillae Trace, Wilks' Lambda Hotelling's Trace, dan Roy's Largest Root statistics which produce an $F$ co-efficient of $6.582^{\mathrm{a}}$ with a significance score of Sig. $=$ .003. This means that there are simultaneous significant differences in the SSE learning achievements and nationalism attitudes between the group of students who follow the projectbased evaluation with nationalism insight activities and those who follow conventionalbased evaluation learning. Second, results of the analysis of the Tests of Between-Subjects Effects show an $F$ score of 12.300 with a significance level of .001 , which is lower than .05. This means that there is a significant impact of the project-based evaluation learning model with nationalism insight activities on the SSE learning achievements of the $4^{\text {th }}$ grade students of the primary school. Third, results of the analysis of the Tests of Between-Subjects Effects show an $F$ score of 5.727 with a significance level of .021 , which is lower than .05. This means that there is a significant impact of the project-based evaluation learning model with nationalism insight activities on the nationalism attitudes of the $4^{\text {th }}$ grade students of the primary school.

Table 4. Results of the Multi-variate Analyses of the Model

\begin{tabular}{lccccc}
\hline Effect & Value & $\boldsymbol{F}$ & Hypothesis $\boldsymbol{d} \boldsymbol{f}$ & Error $\boldsymbol{d} \boldsymbol{f}$ & Sig. \\
\hline Pillai's Trace & .234 & $6.582^{\mathrm{a}}$ & 2.000 & 43.000 & .003 \\
Wilks' Lambda & .766 & $6.582^{\mathrm{a}}$ & 2.000 & 43.000 & .003 \\
Hotelling's Trace & .306 & $6.582^{\mathrm{a}}$ & 2.000 & 43.000 & .003 \\
Roy's Largest Root & .306 & $6.582^{\mathrm{a}}$ & 2.000 & 43.000 & .003 \\
\hline
\end{tabular}

Table 5. Results of Analisis Tests of Between-Subjects Effects of the Model

\begin{tabular}{|c|c|c|c|c|c|c|c|}
\hline Source & Dependent Variable & $\begin{array}{l}\text { Type III Sum } \\
\text { of Squares }\end{array}$ & $d f$ & $\begin{array}{l}\text { Mean } \\
\text { Square }\end{array}$ & $\boldsymbol{F}$ & Sig. & $\begin{array}{c}\text { Partial Eta } \\
\text { Square }\end{array}$ \\
\hline \multirow[t]{2}{*}{ Main effect } & Learn_Achiev & 1083.535 & 1 & 1083.535 & 12.300 & .001 & .925 \\
\hline & Nationalism_Attitudes & 285.654 & 1 & 285.654 & 5.727 & .021 & .851 \\
\hline \multirow[t]{2}{*}{ Error } & Learn_Achiev & 3875.943 & 44 & 88.090 & & & \\
\hline & Nationalism_Attitudes & 2194.716 & 44 & 49.880 & & & \\
\hline \multirow[t]{2}{*}{ Total } & Learn_Achiev & 310666.000 & 46 & & & & \\
\hline & Nationalism_Attitudes & 309983.000 & 46 & & & & \\
\hline \multirow[t]{2}{*}{ Corrected total } & Learn_Achiev & 4959.478 & 45 & & & & \\
\hline & Nationalism_Attitudes & 2480.370 & 45 & & & & \\
\hline
\end{tabular}

\section{Discussion}

The results of the data analyses show that there are simultaneous differences in the SSE learning achievement between the group of students who follow the learning model of the project-based evaluation focusing onnationalisminsight activities and the group of students who follow the learning model using conventionalbased evaluation. The instructional activities in the experiment class are oriented towards the stages that are taken in a project evaluation which are based on nationalism insights. Treatment of the learning procedures in this class gives an impact on the manner by which the instructional materials is presented. Project assessment based on nationalism insights gives the opportunity for students to be active, independent, and responsible in the learning process. In this way, aspects of the students' skills and attitudes can be developed simultaneously. It is important for students to feel that they can evaluate what they have learned which subsequently will give them self-confidence and motivation in their learning processes (Carpenter, Witherby, \& Tauber, 2020).

Evaluation will give students choice of 
whether they will study or they will not study (Zainuddin, Shujahat, Haruna, \& Chu, 2020; Saenz \& Smith, 2018). This is learning that gives a great impact on students' growth. Students, who formerly do not want to listen to their peer's opinions, now grow to like listening to their friends' talks. They, who are reluctant to actively participate in doing group assignments, grow to be very active. The results of the study have indicated that the use of the project-based evaluation approach helps improve the students' learning achievement and social attitudes. These social attitudes are nationalism such as tolerance, appreciative of others' opinions, and responsibility. Students are confronted with problems that exite their curiosities to investigate so that they can communicate the answers and results to other people. This is similar to the PjBL learning model, with the difference that it focuses on project-based evaluation combined with the aspects of nationalism insights, both in the assigning of the problem and the running of the project to solve daily-life problems. It is why students will be able to understand the intellectual aspect (knowledge), emotional aspect (being able to exercise self-control in working in groups), and social aspect (fair in choosing peer, tolerant, and cooperative).

There is a significant influence of the project-evaluation learning model focused on nationalism insights towards SSE learning achievement of the fourth grade students of the primary school. One reason for the different SSE learning achievement between students who are in the project-based evaluation class and those who are in the conventional evaluation class is that the former learning model gives broad opportunity for the students to be active and creative during the instructional processes. Students are allowed to be creative in carrying out the project assignment that must be completed. Project evaluation emphasizes researchoriented assignments towards the problem in the instructional material starting from planning, data collection, data management, data presentation, to report writing (Bressane, da Silva, Fiore, Carra, Ewbank, De-Carli, \& da Mota, 2020). By carrying out a project assignment, students will be able to understand, implement, research, and communicate their findings. Through these stages in the evaluation activities, students can be seen to be more active, creative, independent, and capable of making relations among the different aspects of knowledge that they should practice in their daily life.

A learning system that makes the learners active will have a positive impact on the learners' achievement since the learners feel that their learning is meaningful. Learners who are active participating in the learning process will make the learning more meaningful. One of the ways in which learners are able to obtain new experiences and develop their emotional intelligences is the constructivistic model (Angela, 2014; Kostiainen, Ukskoski, Ruohotie, Kauppinen, Kainulainen, \& Mäkinen, 2018). Experiences can be obtained by the learners through problem solving activities carried out in a scientific process so that evidence can be produced from the instructional process in the form of experiences that can be practiced in life in the society. This is supported by (Chiang \& Lee, 2016) who state that project learning helps the students in improving their motivation and abilities in solving problems. Giving a project to students will help them to be more active in the learning processes, grow the feel of collaboration, increase their self-confidence, and be more motivated in completing the project. Project learning is an effective mode to be implemented in the instructional processes (Chiang \& Lee, 2016). However, as it can be seen in the present study, not all implementations of project learning bring about successful results. Project learning does not produce significant differences between the experiment and control groups because the instructional activities are too heavy for the students to do (Kizkapan \& Bektas, 2017). In order for a project learning to run well, a substantial measure of students' adaptation is needed.

There is a significant impact of the use of the project-based evaluation learning with a focus on nationalism insights towards the nationalism attitudes of the fourth grade of the primary school. One reason that can be identified is the fact that the presentation of the instructional material is packaged in a project-assessment design based on nationalism insights in the forms of projects of a play staging, composition of a national anthem, role playing, comic writing, the making of a historical calendar, and producing a wall magazine. Students hold a group discussion concerning problems that need to be solved and 
each group designs a project under the guidance of the teacher from planning and presentation to reporting. They publish the results and report of the project to be responded to and commented by other students. Finally, the teacher gives the process and product evaluation and comments that are oriented to nasionalism insights. Learning that makes use the involvement of the students' peer gives a positive impacts on the students' character building. Good relation among peers is an effective medium to increase students' interest in the learning processes. Learning in intensive cooperation with peers enhances students' active participation in the instructional processes (Silverman, Artzi, McNeish, Hartranft, Martin-Beltran, \& Peercy, 2019; Tsuei, 2012). Involvement of peers in learning improves the quality of the learning process; students obtain experiences from peers' feedbacks (Gabriele, Holthaus, \& Boulet, 2016). Peers help, lead, guide, and support each other to build learning through interaction and collaboration (Andersen \& Watkins, 2018).

Learning which involves peers decreases anxieties and stresses through the supports and feedbacks from each other. Muhammad, Jampel, \& Widiana (2016) find that there is a significant difference in scientific critical thinking skills between students who join the PBI learning model and and project-based assessment and students who join the conventional model in virtually all the instructional phases of preparation, presentation, exercises, and end processes of presenting results. This is supproted by the study by (Lestari, Parmiti, \& Widiana, 2016) that states that problem-based learning is suitable for classes that use project evaluation learning since, in the problem-based instruction, students are active in working on a problem with the teacher functioning merely as a facilitator. In the same virtues as the problembased learning, the project-evaluation model is suitable for clearly understanding the contents and acquiring the abilities to practice, research, and communicate results in many subject-matter classes. In this relation, use of the projectassessment model oriented to nationalism is highly useful in enhancing students' enthusiasm and activeness in learning.

The important finding of the present study is related to the positive influence of the project- based assessment model oriented on nationalisminsight activities over the students' SSE learning achievements and nationalism attitudes. During the learning processes, the project-based assessment model has changed the instructional activities from the teacher-centred mode to the learner-centred mode. The teacher plays the role of a mere facilitator while the students actively carry out the class activities starting from doing the project, holding a discussion, developing their creativities, to sharing their experiences among each other. The teacher plays the role as a motivator and facilitator. In the project evaluation model, the students are given the opportunity to play an active role in problem solving during the learning process. This is in line with (Sukmasari \& Rosana, 2017) who state that project evaluation is one of the assessment aspect that stimulate students to think at a higher level of the cognitive domains, one of which is problem solving.

In contrast, students in a conventional class spend most of the time listening to the teacher. This takes away the students' opportunities to grow and develop their creativities in doing class assignments. In the conventional learning, the teacher seems to keep transferring his or her knowledge to the students (Wardana, Setuti, \& Sudatha, 2013). In a conventional class, the teacher explains the material in a fixed order, the students may only ask questions and take notes, the teacher gives the exercises, and the students discuss the exercises. At the end of the class, the teacher leads the students to reflect on the material that has been studied and then gives home assignments. This process of learning tends to make the students unmotivated, not able to understand material concepts deeply, and find it difficult to develop their thinking abilities.

Differences in nationalism insights between students who follow the class with the project evaluation model and nationalisminsight activities and those who follow the class with the conventional treatment are due to the different treatments given during the teaching learning processes. In the experiment class, the instructional activities refer to the stages in the project-based evaluation oriented on nationalism insights. The project-based assessment instruction gives the students the freedom to expose their ideas concerning the project such 
that their attitudes in the learning process can be developed. Project-based assessment learning emphasizes on the assigning of research in the form of a problem that is related to the class material through all the stages of planning, data collection, data management, data presentation, and report writing.

By having a task to complete, students will have the abilities to understand, practice, research, and communicate their knowledge. In the proceding of the project-based assessment learning, it can be seen that students become more active, self-confident, and responsible in completing their school assignment. The projectassessment learning also can develop students' characters since, in the learning processes that are oriented to nationalism insights, students' nationalism stature will develop from the instructional processes by showing out the attitudes of cooperation, hard working, appreciating opinions, responsibility, and tolerance. By working together in groups with friends, students are trained to reveal opinions and ideas and accept opinions and ideas of others so that their social attitudes can develop and improve. Such social attitudes become one of the indicators of nationalism attitudes which state that students must have the cooperativeness character to wok together with other people despite differences in ethnic groups, religions, skin colours, and others.

\section{CONCLUSION}

The project-based assessment learning model oriented on nationalism-insight activities can influence students' SSE learning achievement and nasionalism attitudes. This finding is explained by the fact that the learning model gives the opportunity for the students to be active in the learning activities without pressure from the teacher. In this learning model, students work together cooperatively with peers such that they can lighten their burdens in the learning processes. Further study may follow in particular to see whether the impact will last in longer period.

\section{ACKNOWLEDGEMENTS}

The researchers would like to thank the Ganesha Education University for funding this research project.

\section{REFERENCES}

Andersen, T., \& Watkins, K. (2018). The value of peer mentorship as an educational strategy in nursing. Journal of Nursing Education, 57(4), 217-224. https://doi. org/10.3928/01484834-20180322-05.

Andewi, P. L., Suara, I. M., \& Wiyasa, I. K. N. (2015). Penerapan pendekatan saintifik dengan penilaian proyek untuk meningkatkan hasil belajar keterampilan IPS dan kemampuan pemahaman konsep tema cita-citaku siswa kelas IVA SD Negeri 2 Padangsambian. [Application of a scientific approach with project appraisal to improve learning outcomes of social studies skills and the ability to understand the concept of the theme of my ideals in grade IV SD Negeri 2 Padangsambian]. MIMBAR PGSD Undiksha, 3(1), 1-10. https://ejournal.undiksha.ac.id/index.php/ JJPGSD/article/view/4959.

Angela, T. (2014). Challenges to meaningful learning in social studies - the key competences as an opportunity to students' active participation. Procedia - Social and Behavioral Sciences, 128, 192-197. https://doi.org/10.1016/j. sbspro.2014.03.142.

Black, P., \& Wiliam, D. (2018). Classroom assessment and pedagogy. Assessment in Education: Principles, Policy and Practice, 25(6), 551-575. https://doi.org/ 10.1080/0969594X.2018.1441807.

Bressane, A., da Silva, P. M., Fiore, F. A., Carra, T. A., Ewbank, H., De-Carli, B. P., \& da Mota, M. T. (2020). Fuzzy-based computational intelligence to support screening decision in environmental impact assessment: A complementary tool for a case-by-case project appraisal. Environmental Impact Assessment Review, 85, 1-9. https://doi.org/10.1016/j. eiar.2020.106446.

Budiarto, G. (2020). Indonesia dalam pusaran globalisasi dan pengaruhnya terhadap krisis moral dan karakter. Jurnal Pamator, 13(1), 50-56. https://doi.org/10.21107/ pamator.v13i1.6912. 
Carpenter, S. K., Witherby, A. E., \& Tauber, S. K. (2020). On students' (Mis)judgments of learning and teaching effectiveness. Journal of Applied Research in Memory and Cognition, 9(2), 137-151. https://doi. org/10.1016/j.jarmac.2019.12.009.

Chiang, C. L., \& Lee, H. (2016). The effect of project-based learning on learning motivation and problem-solving ability of vocational high school students. International Journal of Information and Education Technology, 6(9), 709712. https://doi.org/10.7763/IJIET.2016. V6.779.

DeLuca, C., Luu, K., Sun, Y., \& Klinger, D. A. (2012). Assessment for learning in the classroom: Barriers to implementation and possibilities for teacher professional learning. Assessment Matters, 4, 5-29. https://doi.org/10.18296/am.0104.

Farrell, C. (2020). Do international marketing simulations provide an authentic assessment of learning? A student perspective. The International Journal of Management Education, 18(1), $1-13$. ijme.2020.100362.

Fazriah, W. D., Suara, I. M., \& Wiyasa, I. K. N. (2015). Penerapan pendekatan saintifik denganpenilaianproyek untuk meningkatkan hasil belajar pengetahuan IPS dan kemampuan penalaran kelas IV SD Negeri 26 Pemecutan. [Application of a scientific approach with project assessment to improve learning outcomes of social studies knowledge and reasoning skills of grade IV SD Negeri 26 Pemecutan]. MIMBAR PGSD Undiksha, 3(1), 1-11. https://ejournal. undiksha.ac.id/index.php/JJPGSD/article/ view/4958.

Furqan, M. H., Yanti, S., Azis, D., Kamza, M., \& Ruslan, R. (2020). Analisis konten nilai cinta tanah air (nasionalisme) dalam materi mata pelajaran kurikulum geografi. [Analysis of the content of the value of love for the country (nationalism) in the subject matter of the geography curriculum]. Jurnal Serambi Ilmu, 21(1), 48-63. https://doi.org/10.32672/ si.v21i1.1882.

Gabriele, K. M., Holthaus, R. M., \& Boulet, J. R. (2016). Usefulness of video-assisted peer mentor feedback in undergraduate nursing education. Clinical Simulation in Nursing, 12(8), 337-345. https://doi.org/10.1016/j. ecns.2016.03.004.

Gurung, R. A. R. (2020). Call it out: Recognizing good teaching and learning. Journal of Applied Research in Memory and Cognition, 9, 161-164. https://doi. org/10.1016/j.jarmac.2020.02.003.

Heafner, T. L., \& Fitchett, P. G. (2012). National trends in elementary instruction: Exploring the role of social studies curricula. The Social Studies, 103(2), 67-72. https://doi. org/10.1080/00377996.2011.592165.

Henriksen, D., Richardson, C., \& Shack, K. (2020). Mindfulness and creativity: Implications for thinking and learning. Thinking Skills and Creativity, 37, 1-10. https://doi.org/10.1016/j.tsc.2020.100689.

Huda, M. J. N., \& Nurwardani, M. (2013). Studi penanaman nasionalisme pada siswa sekolah dasar berbasis agama di Yogyakarta. [Study of planting nationalism in religion-based elementary school students in Yogyakarta]. Jurnal Psikologi Integratif, 1(1), 52-62. http:// ejournal.uin-suka.ac.id/isoshum/PI/ article/view/263/244.

Idris, I., Sida, S. C., \& Idawati, I. (2019). Pengaruh model problem based learning terhadap keterampilan proses dan hasil belajar IPS siswa SD. [The effect of the problem based learning model on the process skills and social studies learning outcomes of elementary school students]. Indonesian Journal of Primary Education, 3(2), 58-63. https://ejournal.upi.edu/ index.php/IJPE/article/view/21849.

Keinänen, M., Ursin, J., \& Nissinen, K. (2018). How to measure students' innovation competences in higher 
education: Evaluation of an assessment tool in authentic learning environments. Studies in Educational Evaluation, 58, 30-36. https://doi.org/10.1016/j. stueduc.2018.05.007.

Kizkapan, O., \& Bektas, O. (2017). The effect of project based learning on seventh grade students' academic achievement. International Journal of Instruction, 10(1), 37-54. https://doi.org/10.12973/ iji.2017.1013a.

Kostiainen, E., Ukskoski, T., Ruohotie-Lyhty, M., Kauppinen, M., Kainulainen, J., \& Mäkinen, T. (2018). Meaningful learning in teacher education. Teaching and Teacher Education, 71, 66-77. https://doi. org/10.1016/j.tate.2017.12.009.

Lee, I., \& Coniam, D. (2013). Introducing assessment for learning for EFL writing in an assessment of learning examinationdriven system in Hong Kong. Journal of Second Language Writing, 22(1), 34-50. $\quad$ https://doi.org/10.1016/j. jslw.2012.11.003.

Lefebvre, O., \& Luo, J. (2020). An authentic learning approach to engage solid waste engineering students. Procedia Computer Science, 172, 748-759. https://doi. org/10.1016/j.procs.2020.05.107.

Leong, W. S., Ismail, H., Costa, J. S., \& Tan, H. B. (2018). Studies in educational evaluation assessment for learning research in East Asian countries. Studies in Educational Evaluation, 59, 270-277. https://doi. org/10.1016/j.stueduc.2018.09.005.

Lestari, N. M. S. A., Parmiti, D. P., \& Widiana, I. W. (2016). Pengaruh model pembelajaran Problem Based Learning (PBL) dan penilaian proyek terhadap kemampuan berpikir kritis IPA siswa. [The effect of the Problem Based Learning (PBL) learning model and project assessment on students' critical thinking skills in science]. MIMBAR PGSD Undiksha, 4(1), 1-10. https://ejournal.undiksha.ac.id/index.php/ JJPGSD/article/view/7677.
Mak, P., \& Lee, I. (2014). Implementing assessment for learning in L2 writing: An activity theory perspective. System, 47, 73-87. https://doi.org/10.1016/j. system.2014.09.018.

Matondang, Z. (2017). Peningkatan hasil belajar siswa dengan menggunakan model pembelajaran listening team pada mata pelajaran IPS. [Improving student learning outcomes using the listening team learning model in social studies subjects]. Anthropos: Jurnal Antropologi Sosial dan Budaya, 3(1), 48-54. https:// doi.org/10.24114/antro.v3i1.7492.

McCulley, L. V., \& Osman, D. J. (2015). Effects of reading instruction on learning outcomes in social studies: A synthesis of quantitative research. Journal of Social Studies Research, 39(4), 183-195. https:// doi.org/10.1016/j.jssr.2015.06.002.

Muhammad, N., Jampel, I. N., \& Widiana, I. W. (2016). Pengaruh model pembelajaran problem based instruction dan penilaian proyek terhadap kemampuan berpikir kritis IPA siswa kelas V. [The effect of the problem-based instruction learning model and project assessment on the critical thinking skills of students in class V]. MIMBAR PGSD Undiksha, 4(1), 1-11. https://ejournal.undiksha.ac.id/index.php/ JJPGSD/article/view/7677.

Nagge, J. J., Killeen, R., \& Jennings, B. (2018). Using a course pilot in the development of an online problem-based learning (PBL) therapeutics course in a postprofessional PharmD program. Currents in Pharmacy Teaching and Learning, 10(2), 231-234. https://doi.org/10.1016/j. cptl.2017.10.005.

Nurdin, N. (2016). Pengaruh motivasi belaajr dan persepsi atas lingkungan sekolah terhadap prestasi belajar Ilmu Pengetahuan Sosial. [The effect of learning motivation and perceptions of the school environment on the learning achievement of the social science]. Cakrawala Pendidikan, 35(1), 98-105. https://doi.org/10.21831/ cp.v35i1.28269. 
Ollila, J., \& Macy, M. (2018). Social studies curriculum integration in elementary classrooms: Acase study on a Pennsylvania Rural school. The Journal of Social Studies Research, 43(1), 33-45. https:// doi.org/10.1016/j.jssr.2018.02.001.

Ranalli, J., Feng, H. -H., \& ChukharevHudilainen, E. (2018). Exploring the potential of process-tracing technologies to support assessment for learning of L2 writing. Assessing Writing, 36, 77-89. https://doi.org/10.1016/j. asw.2018.03.007.

Rosidah, A. (2017). Penerapan model pembelajaran kooperatif snowball throwing untuk meningkatkan hasil belajar siswa pada pembelajaran IPS. [Application of the snowball throwing cooperative learning model to improve student learning outcomes in social studies learning]. Jurnal Cakrawala Pendas, 3(2), 29-36. https://doi.org/10.31949/jcp. v3i2.593.

Rusmawan, R. (2013). Faktor yang memengaruhi kesulitan belajar IPS siswa sekolah dasar. [Factors Affecting Learning Difficulties In Social Studies Among Elementary School Students]. Cakrawala Pendidikan, 32(2), 285-295. https://doi.org/10.21831/ cp.v0i2.1487.

Saenz, G. D., \& Smith, S. M. (2018). Testing judgments of learning in new contexts to reduce confidence. Journal of Applied Research in Memory and Cognition, 7(4), 540-551. https://doi.org/10.1016/j. jarmac.2018.07.003.

Sari, M. K. (2014). Pengaruh metode kooperatif jigsaw terhadap prestasi belajar mata pelajaran IPS siswa kelas III. [The influence of the jigsaw cooperative method on the learning achievement of social studies subjects in grade III students]. Premiere Educandum, 4(2), 133-146. http://doi.org/10.25273/pe.v4i02.313.

Sari, R. P., Mauliza, M., Nazar, M., \& Nahadi, N. (2020). The implementation of performance assessment through virtual laboratory to college students' creative thinking skills. Jurnal Penelitian Pendidikan IPA, 7(1), 5-10. http://doi. org/10.29303/jppipa.v7i1.484.

Şendağ, S., \& Odabaşi, H. F. (2009). Effects of an online problem based learning course on content knowledge acquisition and critical thinking skills. Computers and Education, 53(1), 132-141. https://doi. org/10.1016/j.compedu.2009.01.008.

Setiawan, R. (2017). Pembangunan nilai demokrasi dan nasionalisme sebagai kurikulum tersembunyi di SMAN CMBBS. [Development of democratic values and nationalism as a hidden curriculum in SMAN CMBBS]. Hermeneutika: Jurnal Hermeneutika, 3(1), 10-20. https://doi.org/10.30870/ hermeneutika.v3i1.3010.

Setyasto, N., \& Wijayama, B. (2017). Penerapan perangkat pembelajaran IPS Model Think Pair Share (TPS) dengan media video untuk meningkatkan karakter, aktivitas dan hasil belajar siswa. [The application of the Think Pair Share (TPS) Model of Social Studies learning tools with video media to improve character, activities and student learning outcomes]. Jurnal Pendidikan, 2(2), 128-133. http://dx.doi. org/10.26740/jp.v2n2.p128-133.

Shariff, S. M., Johan, Z. J., \& Jamil, N. A. (2013). Assessment of project management skills and learning outcomes in students' projects. Procedia - Social And Behavioral Sciences, 90, 745-754. https://doi. org/10.1016/j.sbspro.2013.07.148.

Silverman, R. D., Artzi, L., McNeish, D. M., Hartranft, A. M., MartinBeltran, M., \& Peercy, M. (2019). The relationship between media type and vocabulary learning in a cross age peerlearning program for linguistically diverse elementary school students. Contemporary Educational Psychology, 56, 106-116. https://doi.org/10.1016/j. cedpsych.2018.12.004. 
Sukmasari, V. P., \& Rosana, D. (2017). Pengembangan penilaian proyek pembelajaran IPA berbasis discovery learning untuk mengukur keterampilan pemecahan masalah. [Developing discovery-learning based natural sciences learning project assessment to assess problem solving skill]. Jurnal Inovasi Pendidikan IPA, 3(1), 101-110. https:// doi.org/10.21831/jipi.v3i1.10468.

Sulfemi, W. B. (2019). Model pembelajaran kooperatif mind mapping berbantu audio visual dalam meningkatkan minat, motivasi dan hasil belajar IPS. [The mind mapping cooperative learning model supports audio-visuals in increasing interest, motivation and social studies learning outcomes]. Jurnal PIPSI (Jurnal Pendidikan IPS Indonesia), 4(1), 1319. http://dx.doi.org/10.26737/jpipsi. v4i1.1204.

Suryani, E., \& Aman, A. (2019). Efektivitas pembelajaran IPS melalui implementasi metode jigsaw ditinjau dari aktivitas dan hasil belajar. [The effectiveness of social studies learning through the implementation of the jigsaw method in terms of activities and learning outcomes]. Harmoni Sosial: Jurnal Pendidikan IPS, 6(1), 34-48. https://doi.org/10.21831/ hsjpi.v6i1.17376.

Tsuei, M.(2012).Using synchronous peertutoring system to promote elementary students' learning in mathematics. Computers and Education, 58(4), 1171-1182. https://doi. org/10.1016/j.compedu.2011.11.025.

Tungkasamit, A., \& Junpeng, P. (2012). The development of authentic assessment training curriculum for research-based learning class in higher education of Thailand.Procedia-SocialAndBehavioral Sciences, 69, 1168-1173. https://doi. org/10.1016/j.sbspro.2012.12.047.
Wahyuni, I., Slameto, S., \& Setyaningtyas, E. W. (2018). Penerapan model PBL berbantuan role playing untuk meningkatan motivasi dan hasil belajar IPS. [The application of role playing-assisted PBL models to increase motivation and social studies learning outcomes]. Jurnal Ilmiah Sekolah Dasar, 2(4), 356-363. http:// dx.doi.org/10.23887/jisd.v2i4.16152.

Wardana, I. W. S., Setuti, N. M., \& Sudatha, I. G. W. (2013). Pengaruh model pembelajaran group investigation berbantuan asesmen proyek terhadap prestasi belajar IPA siswa kelas V sekolah dasar gugus III Tampaksiring. [The effect of the group investigation learning model assisted by project assessment on the science learning achievement of class $\mathrm{V}$ elementary school class III Tampaksiring students]. MIMBAR PGSD Undiksha, 1(1), 1-10. https://ejournal.undiksha.ac.id/index.php/ JJPGSD/article/view/1196.

Widnyani, N. P. P., Suara, I. M., \& Wiyasa, I. K. N. (2015). Penerapan pendekatan saintifik dengan penilaian proyek untuk meningkatkan hasil belajar IPS dan kemampuan berpikir kreatif siswa kelas IV SD. [Application of a scientific approach with project appraisal to improve social studies learning outcomes and creative thinking skills of fourth grade elementary school students]. MIMBAR PGSD Undiksha, 3(1), 1-11. https://ejournal. undiksha.ac.id/index.php/JJPGSD/article/ view/4943.

Zainuddin, Z., Shujahat, M., Haruna, H., \& Chu, S. K. W. (2020). The role of gamified e-quizzes on student learning and engagement: An interactive gamification solution for a formative assessment system. Computers and Education, 145, 1-48. https://doi.org/10.1016/j. compedu.2019.103729. 